\title{
Televisi dan Fenomena Kekerasan Perspektif Teori Kultivasi
}

\author{
Nova Yuliati
}

\author{
ABSTRACT
}

$T V$ violence becomes one of the main polemics nowadays. Communication experts, media activists, and parents are strongly opposed and debated bad TV content due to its effect on children's aggressive behavior. As stated by George Gerbner, communication expert who theorized Cultivation Theory, TV power comes from the symbolic content of the real-life drama shown hour per hour, week after week. Furthermore, television is easy to access and relatively cheap. More than 90 percent residents watch TV everyday. Cultivation theory theorized by Gerbner recently has developed and gave birth many other theories such as mainstreaming, resonance, desensitization, and priming.

Kata kunci: kekerasan, teori kultivasi, mainstreaming, resonance

\section{Pendahuluan}

Di era informasi seperti saat ini, media massa berperan penting dalam kehidupan kita. Boleh dikata, hampir sebagian besar penduduk dunia melek media. Media memberi implikasi besar pada kehidupan kita di masa kini dengan bobot yang semakin hari semakin besar (banyak) baik secara kuantitas maupun kualitas. Salah satu kekuatan media massa adalah kemampuannya menciptakan "lingkungan semu" bagi khalayaknya. Walter Lippman dalam bukunya yang berjudul Public Opinion (1922) menguraikan gagasannya sebagai berikut:

"Biasanya, kita tidak melihat dulu sesuatu untuk mendefinisikannya; biasanya kita mendefinisikan dulu, baru melihat. Ketika diliputi ketidaktahuan tentang dunia luar, kita begitu saja membayangkannya berdasarkan apa yang sudah kita ketahui. Karena itulah kita sering terjebak stereotype...." (Rivers, Jense, \& Peterson: 2000:29).
Lippman menguraikan hal itu sebagai bagian dari ulasannya tentang opini publik dan surat kabar. Namun, konsepsinya bisa diterapkan ke semua jenis media. Sebagai sumber pengetahuan, media menyajikan informasi dunia luar kepada orang-orang, yang kemudian menggunakannya untuk membentuk atau menyesuaikan gambaran mentalnya tentang dunia (Rivers, Jense, \& Peterson: 2003:30). Gagasan Lippman mengenai kenyataan bentukan media massa yang diutarakannya di tahun 1922 semakin menemukan bentuknya di era informasi sekarang. Pada titik ini, mau tidak mau kita harus mengakui bahwa media massa memiliki daya pengaruh terhadap cara pandang, perasaan, bahkan perilaku kita melalui 'objektivitas semu' yang dapat dikonstruksinya.

Setiap bentuk media massa memiliki karakteristik khas dengan berbagai kelebihan dan kekurangannya. Di antara berbagai bentuk media massa, yang mungkin paling kontroversial adalah televisi. Televisi (melalui program-programnya) 
tidak saja memasuki wilayah publik, juga menyerbu wilayah-wilayah pribadi kita. Televisi memasuki kantor, ruang-ruang keluarga, bahkan kamar tidur berjam-jam setiap harinya.

\section{Fenomena Televisi}

Televisi membawa berbagai kandungan informasi atau pesan yang menyebar dalam kecepatan tinggi ke seluruh pelosok. Ia menjadi alat bagi aneka kelompok untuk menyampaikan aneka pesan bagi berbagai khalayak. Melalui berbagai macam program tayangannya, baik yang berdasarkan realitas maupun rekaan, televisi bisa menjadi wahana belajar bagi siapa saja; televisi telah menjadi second mother, di mana anak belajar dari televisi. Seorang anak melompat dari atap rumah setelah menonton seorang jagoan yang melompat dari atap gedung pada sebuah tayangan televisi. Pada kali lain, seorang anak menyerahkan celengannya hasil menabung berbulan-bulan yang tadinya akan digunakan untuk membeli apa yang diinginkannya pada korban tsunami di Aceh setelah ia melihat musibah itu di televisi.

Namun, tanpa mengabaikan dampak positif yang ditimbulkannya, banyak kalangan mencemaskan pengaruh negatif televisi terhadap perilaku khalayak. Maraknya tayangan-tayangan kekerasan di televisi menyulut kembali efek media violence. Hal ini bukan tak berdasar, kita perhatikan hasil penelitian Amirudin pada tahun 1996:

"Sebanyak 33 anak dari 40 anak usia 5 sampai dengan 14 tahun di Semarang mengaku telah memperoleh pengetahuan kekerasan melalui televisi. Di antara mereka, 26 orang anak merasa terdorong dan ikut serta melakukan tindak kekerasan setelah mereka menikmati berbagai adegan kekerasan yang ditayangkan flm-film di televisi. (Amirudin:2000:29).

Peristiwa di Amerika Serikat berikut ini juga menunjukkan gejala serupa.

Pada 20 April 1999 di Columbine High School,

Littleton, Colorado Amerika Serikat terjadi penembakan yang dilakukan dua siswa pemuda sekolah tersebut, Dylan Klebold (18 th) dan Eric

Harris (17 th). Mereka secara membabi buta menembaki sekolah itu. Insiden tersebut menewaskan tidak kurang 12 orang murid dan seorang guru tewas, serta lebih dari 20 orang lukaluka. Kedua pelaku-Dylan dan Eric-seusai kejadian mengerikan itu bunuh diri dengan menembak dirinya sendiri. Pada akhirnya terungkap bahwa para pelaku adalah penggemar acara-acara kekerasan di televisi. (Astuti, 2004)

\section{Teori Kultivasi}

Pencetus Teori Kultivasi, George Gerbner, menganggap televisi sebagai sebuah kekuatan yang dominan dalam kehidupan di zaman modern ini. Argumen Gerbner didasarkan pada kenyataan bahwa televisi telah menjadi semacam 'anggota keluarga baru' di mana ia memiliki akses tak terbatas terhadap setiap anggota keluarga. Dalam bahasa yang lebih ekstrim, Gerbner bahkan menuding televisi sebagai agama baru, karena menonton televisi tidak ubahnya bagaikan ritual keagamaan seperti pergi ke gereja bagi pemeluk Kristiani.

Lantas, apa yang paling mengasyikkan yang ditonton pemirsa televisi setiap harinya? Gerbner menunjuk tayangan-tayangan kekerasan-lah yang mereka sukai. Pendapat Gerbner tentang efek negatif televisi hanya salah satu dari banyak teori yang menghubungkan efek media dengan kekerasan. Ditengarai bahwa selain televisi, jenis-jenis media lain semacam buku-buku komik, atau video games juga mengakibatkan efek negatif, tapi bagi Gerbner, televisi adalah 'tersangka utama'. Keyakinannya itu berdasarkan pada penelitian yang telah dilakukannya. Selama hampir dua dekade, Gerbner telah memelopori riset yang intensif tentang hubungan tayangan (program) televisi dengan tingkat kekerasan, ia juga mengategorisasikan atau mengelompokkan penonton berdasarkan intensitas (lamanya) mereka menonton televisi, serta perilakuperilaku lainnya.

Televisi-berbeda dari media massa lainnya, memproduksi beragam acara di mana pesan-pesan yang disampaikannya membentuk citra realitas yang begitu logis, yang lantas disampaikan kepada khalayak luas. Televisi ditonton khalayak dengan tingkat selektivitas yang rendah, di mana agenda menonton masyarakat nyaris merupakan sebuah ritual. Oleh karenanya, televisi melalui pesan- 
pesannya mengonstruksi suatu cara pandang baru tentang dunia kehidupan, bahkan menciptakan semacam ideologi baru bagi masyarakat.

Teori Kultivasi George Gerbner menyoroti efek televisi yang kumulatif dan akhirnya membentuk sebuah realitas baru sesuai citra realitas yang ditampilkan di televisi. Artinya, kita memandang dunia di mana kita tinggal sesuai dengan citra yang ditampilkan melalui televisi. Dengan kata lain, Teori Kultivasi menekankan pengaruh televisi yang sangat kuat terhadap pembentukan persepsi publik yang pada akhirnya melahirkan kontruksi sosial (Miller:270).

George Gerbner tidak puas terhadap penelitianpenelitian tradisional yang menelaah media massa sebagai suatu gejala yang terpisah dari sistem sosial. Tanpa mengesampingkan perlunya menelaah spesifikasi program, tingkat selektivitas ataupun perbedaan-perbedaan individu dan kelompok, penelitian-penelitian tradisional memiliki risikoluput mengamati kekuatan televisi sebagai-dalam bahasa Gerbner- the common story teller yang begitu signifikan dan nyata di abad ini.

Penelitian-penelitian terdahulu berfokus hanya pada efek-efek kognitif, afektif, dan behavioral semata, dan tidak mengikutsertakan 'efek ideologis' dari televisi. Menurut Gerbner,

"TV's power comes from the symbolic content of the real-life drama shown hour per hour, week after week. At its root, television is society,s institutional story teller, and a society,s stories give " a coherent picture of what exist, what is important, what is related to what, and what is right." (Griffin:380)

Gerbner melihat bahwa setiap masyarakat memiliki serangkaian penjelasan tentang realitas. Realitas tersebut adalah gambaran terpadu dan homogen apa yang penting, apa-apa saja yang saling terkait, dan apa yang benar. Setiap kita berusaha menanamkan sejenis aturan yang menegaskan mana yang boleh dan mana yang tidak boleh. Aturan inilah yang disebut dengan ideologi. Dalam konteks media, ideologi ini mewujud dalam bentuk teks, atau pesan-pesan yang diproduksi. Distribusi pesanlah yang lalu menciptakan lingkungan simbolis yang mencerminkan struktur dan fungsi lembaga yang memproduksi pesan itu (Rakhmat: 283).

\subsection{Asumsi Dasar Teori Kultivasi}

Secara skematis, Teori Kultivasi George Gerbner didasarkan pada beberapa asumsi seperti tampak pada Tabel 1 .

Tabel 1. Asumsi Dasar Teori Kultivasi

Televisi adalah media yang unik yang memerlukan studi pendekatan yang spesifik pula

Pesan-pesan televisi membentuk sistem yang koheren, membentuk cara berpikir, cara bertindak, yang pada akhirnya menjadi budaya kita

Sistem Pesan ( isi pesan misalnya ) menciptakan tanda-tanda penanaman realitas

Fokus analisa Kultivasi adalah kontribusi menonton televisi yang berlebihan terhadap pola pikir dan perilaku

Teknologi-teknologi baru lebih banyak menyimpangkan jangkauan pesan-pesan televisi

Fokus Kultivasi terletak pada pemantapan yang meluas dan konsekuensi-konsekuensi yang sama

Sumber: Miller (2002:270)

Nova Yuliati. Televisi dan Fenomena Kekerasan Perspektif Teori Kultivasi 
Dari tabel asumsi-asumsi teori kultivasi di atas, merujuk pada Miller, terdapat sekurangnya tiga hal yang menjadi objek telaahnya, yaitu:

\section{(1) Faktor Televisi.}

Fokus sentral dari analisis kultivasi adalah medium televisi yang khas (unik). Berbagai karakteristik yang dimilikinya menjadikan televisi memiliki kekuatan sebagai sebuah bentuk media. Pertama, televisi sudah sangat meluas. Di Amerika Serikat saja, kini hampir semua keluarga memiliki pesawat televisi, bahkan satu keluarga bisa memiliki lebih dari satu buah televisi. Di Indonesia sendiri, televisi kini bukan lagi menjadi barang mewah, televisi hampir menjadi perabot rumah tangga yang utama yang harus tersedia di setiap rumah tangga. Menilik penempatan televisi yang ditempatkan di ruang-ruang keluarga sebagai sentral ruang, bisa dibayangkan berapa jam yang dihabiskan setiap anggota keluarga menikmati acara-acara televisi. Di Amerika, dilaporkan rata-rata televisi ditonton tujuh jam per hari, di mana setiap anggota keluarga menonton rata-rata selama tiga jam setiap harinya. Bandingkan dengan di Indonesia yang memiliki kebiasaan budaya menontonnya cukup tinggi. Berdasarkan pengamatan selintas, orang Indonesia bisa menghabiskan berjam-jam waktunya di depan televisi. Ketika tidak memiliki aktivitas, kita lebih banyak memilih menonton televisi daripada membaca buku atau beraktivitas lainnya.

Kedua, televisi begitu mudah diakses. Televisi relatif hanya memerlukan sedikit usaha untuk mengaksesnya, bahkan seorang buta aksara pun bisa menikmatinya.

Ketiga, televisi begitu koheren, melalui program-programnya, televisi mengirimkan pesanpesan yang dikemas sedemikian rupa dan tersosialisasi melintasi jarak ruang dan waktu.

\section{(2) Faktor "menonton" televisi}

Teori Kultivasi berkembang dari ide tentang bagaimana kita menonton televisi. Gerbner dkk berpendapat bahwa masyarakat menonton televisi tidak kenal waktu. Teori kultivasi meyakini bahwa seseorang tidak menonton televisi berdasarkan pilihannya, mereka biasanya menonton apa saja yang tersaji. Pada situasi seperti ini, maka penonton cenderung tidak memiliki selektivitas dan hal ini telah menjadi semacam kebiasaan yang selalu berulang.

\section{(3) Efek Kultivasi}

Menilik pada keunikan dan pada peran sentralnya dalam kehidupan kita, Gerbner dkk mengemukakan bahwa televisi akan 'menanamkan' cara pandang terhadap dunia. Gagasannya terletak pada efek penanaman realitas yang meyakini bahwa televisi dapat menciptakan seperangkat kepercayaan atau nilai-nilai baru tentang realitas yang disosialisasikannya dalam jangka waktu yang lama.

Di antara berbagai media, televisi adalah mesin ideologi yang paling ideal (Rakhmat : 283). Televisi adalah sarana utama di mana kita belajar tentang masyarakat dan kultur dan melalui kontak kita dengan televisi kita belajar tentang dunia, orangorangnya, nilai-nilainya serta adat kebiasaannya.

Persepsi tentang dunia ciptaan televisi terbentuk melalui lingkungan simbolis dan sebagai alat untuk menelaahnya, Gerbner menggunakan apa yang dinamakan sebagai indikator kultural. Rakhmat menunjukkan indikator kultural melingkupi aspek-aspek:

- Apa hubungan antara lembaga media massa dengan lembaga-lembaga lain?

- Bagaimana dan pada tingkat mana diambil keputusan tentang pesan?

- Apa pengaruh kekuasaan, peranan, dan hubungan sosial terhadap proses pemilihan, perumusan dan penyebaran pesan? (1988:283).

\subsection{Kekerasan dalam Perspektif Teori Kultivasi}

Eskalasi kekerasan di layar televisi mencemaskan banyak pihak mulai dari orang-tua, guru, sampai pemerhati media. Tapi kemudian muncul pertanyaan 'apa yang dimaksud dengan kekerasan? Apa saja yang terkategorisasi sebagai kekerasan? Gerbner membuat kategori kekerasan dengan seperangkat pengukuran yang objektif, ia memilah mana yang termasuk siaran televisi yang 'bersahabat', dan mana yang menjadi 'musuh'. Gerbner merumuskan bahwa kekerasan (di televisi) 
adalah

"ekspresi atau tampilan yang nyata (gamblang) dari pamer kekuatan fisik (dengan atau tanpa senjata, termasuk di dalamnya menyakiti diri sendiri atau orang lain), adegan-adegan pemaksaan yang menyebabkan orang lain menderita dan terluka serta bentuk-bentuk ancaman terhadap orang lain (Griffin: 381).

Termasuk di dalam kekerasan di sini adalah kekerasan fisikal yang ditampilkan dalam film-film kartun. Sebagai contoh, adegan Power Rangers menghabisi musuh-musuhnya, atau adegan pemukulan dalam film kartun, Gerbner menunjuk adegan-adegan tersebut sebagai 'kekerasan'. Juga tayangan-tayangan bencana alam dan kecelakaan karena walaupun sudah diperhalus sedemikian rupa (untuk alasan artistik), tetap saja tayangantayangan tadi bukan suatu kebetulan belaka. Sang penulis naskah telah menyisipkan efek dramatik yang traumatis karena ada karater-karakter yang tercederai atau bahkan mati.

Untuk melihat betapa banyaknya tayangan kekerasan di televisi, mungkin data yang disampaikan Nancy Signorielli ini membuat kita terhenyak. Menurutnya, terhitung tahun 19671985, sekitar $71 \%$ dari tayangan prime time diisi kekerasan. Sementara $94 \%$ tayangan week-end dipenuhi adegan-adegan kekerasan.

\subsection{Penonton Televisi dalam Perspektif Teori Kultivasi}

Selain mendefinikan dan mengategorisasikan jenis-jenis kekerasan dalam tayangan televisi, Gerbner dkk. juga melengkapi analisisnya dengan tipikal penonton televisi. Gerbner mayakini bahwa efek menonton terlalu banyak tayangan televisi tidaklah terbentuk secara instan, ia juga mengabaikan peranan kelompok sebagai kekuatan pengontrol. Dalam Teori Kultivasi terdapat pengelompokan antara light viewers (penonton ringan) dan heavy viewers (penonton berat).

Termasuk ke dalam kelompok light viewers adalah mereka yang menonton televisi sekitar dua jam setiap harinya. Merekalah penonton yang selektif, yang lebih memilih mematikan layar televisi manakala acara kesukaan mereka usai. Lantas, siapa yang termasuk heavy viewers? Mereka adalah penonton yang menonton televisi sedikitnya empat jam setiap harinya. Merekalah yang dimaksud sebagai pecandu berat televisi. Mereka dianggap mengunyah habis apa yang disajikan oleh televisi. Heavy viewers-lah yang menganggap realitas di televisi sebagai realitas yang sebenarnya, mereka secara konsisten meyakini bahwa realitas di dunia nyata sama persis seperti apa yang ditayangkan pada televisi.

Teori kultivaasi berpendapat bahwa pecandu berat televisi membentuk suatu citra realitas yang tidak konsisten dengan kenyataan. Sebagai contoh, pecandu berat televisi menganggap kemungkinan seseorang untuk menjadi korban kejahatan adalah 1 berbanding 10 . dalam kenyataan, angkanya adalah 1 berbanding 50 (DeVito: 527).

\subsection{Konsep - Konsep dalam Teori Kultivasi}

\section{(1) Mainstreaming}

Mainstreaming adalah istilah yang digunakan Gerbner untuk mendeskripsikan 'kekaburan, pencamburbauran dan penyimpangan' yang menimpa heavy viewers akibat overdosis menonton televisi. Mainstreaming sendiri berarti mengikuti arus. Mainstreaming dimaksudkan sebagai kesamaan di antara pemirsa berat (heavy viewers) pada berbagai kelompok demografis, dan perbedaan dari kesamaan itu pada pemirsa ringan (light viewers). Bila televisi sering kali menyajikan adegan kekerasan, maka penonton berat akan melihat dunia ini dipenuhi kekerasan. Sementara itu penonton ringan akan melihat dunia tidak sesuram seperti penonton berat (Rakhmat, 1988:284)

\section{(2) Resonance}

Resonance adalah proses kecemasan yang menghinggapi para penonton berat akibat terpaan ‘ideologi' televisi. Dalam kehidupan kesehariannya, kebanyakan penonton televisi mungkin pernah mengalami kekerasan - dirampok, berkelahi, kecelakaan mobil, atau sekedar berselisih dengan pacar. Kejadian nyata itu saja sudah demikian 
buruk. Jika kemudian adegan-adegan kekerasan diulang secara terus-menerus di televisi, maka hal itu seperti memutar kembali peristiwa-peristiwa buruk yang dialami oleh pemirsa. Peristiwa itu terus melekat dalam benak mereka. Kejadian sesungguhnya bersama dengan tayangan kekerasan yang terus ditonton akan selalu 'bergema' dalam benak penonton dan semakin kuat membentuk pola-pola penanaman realitas. Pada heavy viewers yang pernah mengalami kekerasan, maka tingkat kecemasannya menjadi dua kali lipat.

Mainstreaming dan resonance ini menumbuhkan keyakinan dalam diri penonton berat bahwa dunia tempat mereka tinggal adalah tempat yang menakutkan

\section{Realitas Media dan Realitas Nyata}

Realitas media merupakan realitas semu yang lantas diyakini oleh khalayak sebagai realitas yang sebenarnya. Dalam konteks penelitian Gerbner, inilah pengaruh televisi terhadap khalayak. Lebih spesifik lagi, ia menyoroti pengaruh kekerasan yang ditayangkan televisi terhadap khalayak. Hasil penelitiannya menunjukkan adanya efek penanaman realitas atau kultivasi pada heavy viewers. Pecandu berat televisi ini menyamakan realitas dunia nyata seperti apa yang mereka lihat pada televisi. Berbagai bentuk kekerasan dan konflik di layar kaca baik berupa drama, pemberitaan, film, dan lain-lain, diyakini sebagai realitas yang sesungguhnya. Televisi, berhasil menanamkan realitas bentukannya kepada penonton, ia tidak lagi hanya sekedar melaporkan dan menginformasikan suatu peristiwa.

Menurut Gerbner dkk., karena televisi merupakan pengalaman besar bersama hampir setiap orang, televisi menyediakan cara bersama melihat dunia (Mulyana, 2004). Lebih jauh, Gerner menjelaskan bagi orang-orang yang banyak meluangkan waktunya dengan media hiburan, sebenarnya menaruh harapan atas dasar fiksi, bukan atas dasar fakta (Jahi, 1988:82). Efek kultivasi ini akan semakin lengkap bila media berhadapan dengan penonton yang pasif, yang tidak memiliki daya analisa dan tidak bertindak kritis terhadap sajian-sajian media. Pada akhirnya, mereka cenderung percaya begitu saja terhadap segala yang ditampilkan lewat media.

Sementara Denis McQuail dan Sven Windahl menyebut faktor 'belajar' dan 'konstruksi' yang merupakan aspek potensial pencetus efek kultivasi. Mereka menggambarkannya dalam bentuk sebagaimana tampak pada Gambar 1.

Gambar 1. Model Pengkondisian Efek Penanaman Realitas.

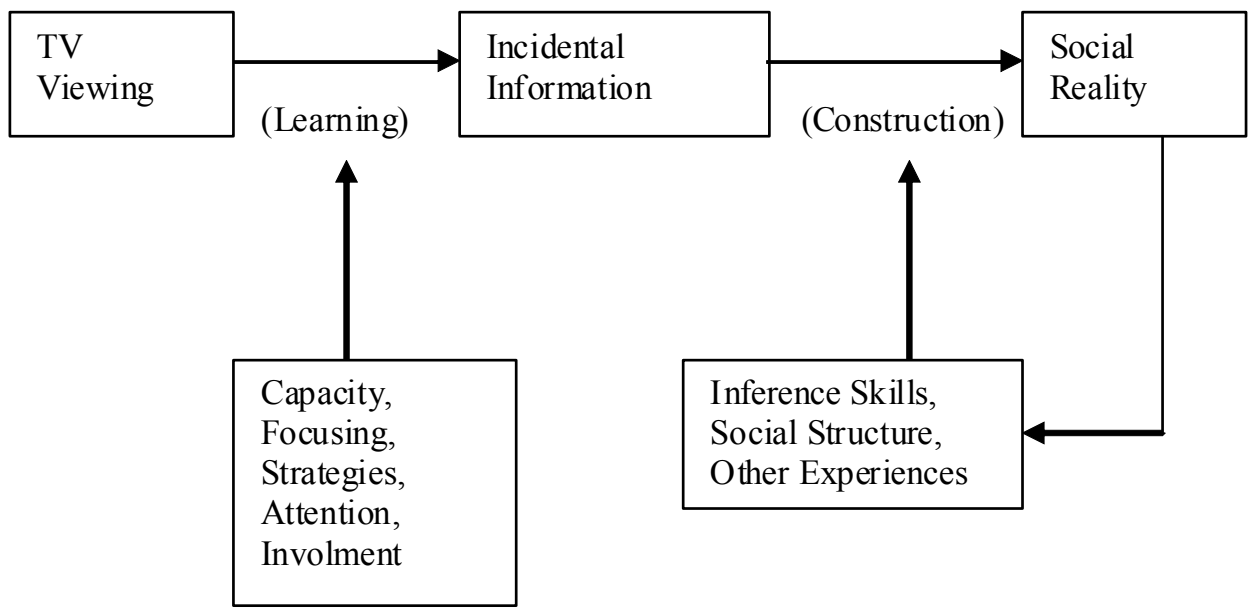


Dari model pada Gambar 1, secara sederhana dapat diurutkan bagaimana efek kultivasi dapat dimunculkan. Namun, proses penanaman efek kultivasi, bila mengacu pada pendapat McQuail, tidaklah tunggal namun berlangsung kompleks karena dipengaruhi berbagai faktor. Seandainya pun televisi sangat berpengaruh, kita tidak dapat mengabaikan berbagai variabel moderator atau moderator perantara yang ikut mempengaruhi pola hubungan (Supriadi, 1993:78).

Namun, terlepas dari banyaknya variabel yang memengaruhi pola hubungan televisi dengan kekerasan, kita tidak dapat mengabaikan efek penanaman realitas yang dikemukakan Gerbner, karena bagaimanapun, dalam masyarakat kontemporer televisi merupakan salah satu kekuatan yang dapat membentuk opini publik atau bahkan menciptakan citra baru dalam masyarakat. Pandangan Amirudin yang juga peneliti ini mungkin bisa sedikit mendeskripsikan efek penanaman realitas dalam kehidupan sehari-hari yang kadang-kadang luput diperhatikan;

Bisa dibayangkan, seandainya dalam satu film ditampilkan tiga puluh kali adegan kekerasan, sedangkan dalam setiap hari mereka (anak-anak) menonton dua atau bahkan tiga film, maka dalam setiap harinya berarti mereka menyaksikan sebanyak 30-90 adegan kekerasan. Jika kemudian dihitung dalam satu minggu, ini berarti terdapat sekitar 630 adegan kekerasan yang dinikmati. Lalu jika dihitung dalam satu bulan berarti ada sekitar 18.900 adegan kekerasan atau bahkan jika dihitung dalam satu tahun berarti ada kekerasan sekitar 1.927.800. Sepertinya, anak-anak hidup dalam wilayah persona, dimana atmosfer kekerasan telah menjadi bagian dari hidupnya, 'diajarkan' dan seolah-olah mereka "diminta" menyelesaikan segala persoalan hidup dengan kekerasan (2000: 31-32).

\section{Kritik terhadap Teori Kultivasi}

Tentu saja, pada setiap pemunculan gagasan, terdapat pro dan kontra. Studi Robert Coles, pakar psikiatri dari Universitas Harvard menemukan, bahwa situasi keluargalah yang menjadi variable moderator hubungan antara tayangan tindak kekerasan di televisi dengan perilaku tertentu pada anak-anak. Coles menunjukkan bahwa memasalahkan tayangan televisi saja tidak cukup tanpa mempertimbangkan kualitas kehidupan keluarga. Kehidupan keluarga yang berkualitas ia artikan sebagai adanya pegangan nilai etik moral dalam keluarga yang sepenuhnya dijungjung tinggi. Dalam hal ini, orang tua menjadi model atau anutan bagi anak, sehingga anak tidak rawan oleh tayangan televisi (Supriadi, 1993:78-79).

Agaknya masih sulit menarik kesimpulan yang meyakinkan tentang seberapa besar dampak siaran televisi, terutama ekspose siaran kekerasan. Kasuskasus kekerasan di masyarakat tentu saja tidak dapat digeneralisasikan sebagai akibat siaran televisi saja, karena begitu banyak stimulus yang disebabkan oleh faktor-faktor lain.

\section{Penutup}

Maraknya tayangan kekerasan di televisi, sudah selayaknya membuat banyak pihak prihatin. Televisi sebagai sumber utama sistem simbol yang repetitive dan ritual, mampu menanamkan kesadaran umum tentang massa khalayak yang paling besar dan heterogen. Keyakinan ini salah satu yang mendasari munculnya Teori Kultivasi yang dikemukakan George Gerbner.

Televisi dengan berbagai kekuatannya seperti telah dipaparkan sebelumnya, membawa implikasi yang sangat signifikan terhadap kehidupan kita, juga disertai dengan efek-efek yang tidak kita bayangkan sebelumnya. Terlepas dari segala kontroversinya, Teori Kultivasi menyadarkan kita untuk mewaspai televisi. Bila Gerbner dkk. mewaspadai televisi dalam konteks isi atau pesanpesannya yang dikemas sedemikian rupa, maka Tony Buzan, seorang pengarang bestseller, penceramah, dan juga trainer 'mendunia', ia memberi anjuran bagi kita untuk "menjaga jarak" dengan televisi. Inilah apa yang disarankan Buzan:

"Periksa lingkungan dan kegiatan Anda di rumah. Ciptakan, daerah bebas televisi. Putuskan untuk tidak mendengarkan atau menonton semua siaran berita (mana pernah acara ini menyiarkan berita gembira?). Jika Anda punya anak, Anda akan tahu bahwa anak-anak menjadi lebih suka mengomel, mudah marah, dan bersikap tidak patuh jika mereka terlalu sering bergonta-ganti hiburan. 
Mereka jauh lebih senang, gembira dan tenang jika dibiarkan menyibukkan diri dengan membaca, atau membiarkannya hanyut dalam imajinasi dan fantasinya sendiri" (203:130-131).

\section{Daftar Pustaka}

Amirudin. 2000. Industri Media Dan Wacana Budaya Kekerasan. Jurnal Ikatan Sarjana Komunikasi. Pt Remaja Rosdakarya.

Astuti. S.I. 2004. "Kekerasan Kriminalitas Di Televisi." Pikiran Rakyat

Buzan, Tony. 2003. Sepuluh Cara Jadi Orang Yang Cerdas Secara Spiritual. Gramedia.

DeVito, Joseph. 1997. Komunikasi Antar Manusia. Professional Books. Jakarta.

Griffin. EM. 2003. A First Look At Communication Theory. Fifth Edition. The McGraw-Hill Companies, Inc.

Jahi. Amri. 1988. Komunikasi Massa Dan Pembangunan Pedesaan Di Dunia Ketiga. Gramedia. Jakarta
Jennings. Bryant, Dolf Zillmann. 2002. Media Effects Advances In Theory And Research. Second Edition. Lawrence Erlbaum Associates, Publisher.

Littlejohn. S.W. 2005. Theories of Human Communication. Eighth Edition. Belmont CA. Wadsworth

McQuail. Denis, Sven Windahl. 1993. Communication Models. Second Edition. Longman. London and New York.1

Miller, Katherine. 2002. Communication Theories, Perspektives, Proceses, And Contexts. The McGraw-Hill Companies. Inc.

Mulyana. Deddy. 2004. "Menangkal Dampak Tayangan Kekerasan, Seksual, Dan Mistik TV Terhadap Anak Dan Remaja." Makalah. Unisba.

Rakhmat. Jalaluddin. 1988. Psikologi Komunikasi. Remadja Karya CV. 